\title{
Assessment the Role of Bisphenol A on Chemotherapeutic Efficacy of Cisplatin against Hepatocellular Carcinoma in Male Rats
}

\author{
Hanaa M. Serag, Magda M. El Komy and Hend S. Ahmed* \\ Zoology Department, Faculty of Science, Mansoura University, Mansoura, Egypt \\ *Corresponding author: Hend Shafiq Ahmed, E-mail: hsh.mit.sci@ gmail.com
}

ABSTRACT

Aim: the objective of this study was to investigate the effect of bisphenol A (BPA) in DENA and $\mathrm{CCl}_{4}$ induced hepatocellular carcinoma male rats. Materials and Methods: DENA was given as a single intraperitoneal injection of freshly prepared $(200 \mathrm{mg} / \mathrm{kg} . \mathrm{bw})$ for initiation the carcinoma and $\mathrm{CCl}_{4}$ once every week ( $3 \mathrm{ml} / \mathrm{kg} . \mathrm{bw})$ for 10 weeks to promote the carcinogenic effect of DENA in male rats. In addition, the study aimed to elucidate the chemo-resistant role of bisphenol A (322 mg/kg.bw) against cisplatin chemotherapeutic effect, as a potent antineoplastic agent in the treatment of hepatocellular carcinoma male rats induced by DENA and $\mathrm{CCl}_{4}$. Results: obtained result showed that the group of rats which was orally administrated by BPA, as well as hepatocellular carcinoma treated rats group significantly have increased relative liver/body weight ratio, serum ALT, AST, ALP, serum total bilirubin, serum total protein and serum AFP and TNF- $\alpha$, serum TL, TC,TG,LDL,V-LDL levels while a decrease in HDL level .Additionally there was an elevation in hepatic MDA, $\mathrm{H}_{2} \mathrm{O}_{2}$ and a significantly depression in SOD, CAT, GST activities and GSH level, as well as an increases in hepatic p53, caspase-3 while a decrease in Bcl-2 level on the other hand an intraperitoneal injection of cisplatin $(1.5 \mathrm{mg} / \mathrm{kg} / \mathrm{bw})$ repeated two times a week for 3 weeks to the hepatocellular carcinoma induced rats group showed amelioration in the above parameters significantly more than that of hepatocellular carcinoma group treated also with BPA. Conclusion: the consumption of BPA might resist the cisplatin chemotherapy treatment of hepatocellular carcinoma in male rats.

Keywords: Hepatocellular carcinoma, Bisphenol A, Cisplatin.

\section{INTRODUCTION}

In a strategic situation in human body the liver is found, it is mainly responsible for metabolic homeostasis regulation by manufacturing energy and molecules used by other cells in nearby or very distant tissues. Liver is an interesting organ with the unique capacity to regenerate upon injury .This selfrepairing ability works as a double-edged sword if the inflicting agent continue or becomes chronic, resulting in cirrhosis, liver failure, and/or development of liver neoplasia . Hepatocellular carcinoma (HCC) is a major health problem worldwide, and represents the fifth most prevalence cause of cancer and the third cause of cancer-related deaths worldwide. For cancer research, animal models of chemically induced carcinogenesis, particularly HCC, have been conducted in rats. Two types of carcinogenic compound are known: genotoxic compounds which are recognized by their capability to induce structural DNA changes, e.x. diethylnitrosamine (DENA) and promoting compounds which lack direct genotoxic capacity, but enhance tumor formation after initiation by a hepatotoxic compound, e.x. carbon tetrachloride, $\mathrm{CCl}_{4}{ }^{[1]}$.Oxidative stress and liver cell injury resulting from reactive oxygen species which involved in $\mathrm{DENA} / \mathrm{CCl}_{4}$ pathogenesis that induce hepatocarcinogenesis ${ }^{[2]}$. Furthermore, DENA is a genotoxic compound which forms alkyl DNA adducts and induces several nuclear abnormalities in rat liver which finally lead to the development of HCC. Cisplatin (CIS) is an effective chemotherapeutic agent that is used in nearly $50 \%$ of all cancer patients. Cisplatin binds with DNA to form intrastrand crosslinks and adducts, then inhibit DNA replication and/or transcription and activate several signal transduction pathways, culminating in the activation of apoptosis. The development of CIS chemoresistance is a major problem with CIS treatment of HCC. Bisphenol A [2, 2-bis (4hydroxyphenyl) propane] (BPA) is one of the highest volume chemicals produced worldwide, and human exposure to BPA is thought to be 
ubiquitous. BPA world-wide production has been grown steadily over the past several decades, with greater than 10 billion pounds produced each year. BPA is an industrial chemical precursor which is widely used in consumer products production, including polycarbonate plastics, epoxy resins, and thermal paper. Polycarbonate plastics are produced by BPA and widely used in a variety of common products, optical, media, automotive, electrical and electronics, housewares and appliances, construction, medical, packaging, etc. ${ }^{[3]}$ BPA ingestion is the main source of contamination which occurs after leaching from food or beverage containers, although its ubiquitous distribution leads also to contamination through the skin, especially in the case of thermal paper. BPA can cause injury in the liver, kidney, and brain in rodents, and other organs by forming reactive oxygen species (ROS), even at low doses ${ }^{[4]}$.

\section{MATERIALS AND METHODS Chemicals}

Diethylnitrosamine (DENA) and carbon tetra chloride $\left(\mathrm{CCL}_{4}\right)$ were purchased from Sigma Chemical Co. (St. Louis, MO, USA). Bispenol A (BPA) was purchased from Alpha Chemika Co. (Mumbai-400 002 INDIA). Cisplatin (CIS) was imported by Ramco M.P.H.REG. Dimethyl sulfoxide (DMSO) was purchased from ElGomhouria Co. Mansoura, Egypt.

\section{Animals and experimental design}

This study was carried out on forty two adult male Wistar albino rats, weighing (100-120g). They were obtained from Helwan animal Farm, Cairo, Egypt. They were housed in steel cages at a well-ventilated animal house. Rats were fed on an adequate standard diet and given water and $a d$ libitum for two weeks of acclimatization period prior to experimentation. The present study complied with the instruction's guidelines and animal received human care. The current experiments were performed in accordance with Institutional Animal Ethics Committee (IAEC) of Mansoura University.

Group-1-(Control): Rats of this group received no treatment.

Group-2-(Corn Oil): A vehicle control group, rats of this group was orally administrated $1 \mathrm{~mL}$
$(0.1 \mathrm{ml} \mathrm{DMSO}+0.9 \mathrm{ml}$ corn oil $) / \mathrm{kg} . b w$ corn oil, for 15 weeks.

Group-3-(BPA): Rats of this group were orally day by day gavaged with bisphenol A (322 mg/kg.bw) dissolved in $1 \mathrm{ml}$ (DMSO) and then diluted in $9 \mathrm{ml}$ corn oil for 15 weeks.

Group-4-(HCC): Rats of this group treated with a single intraperitoneal injection of freshly prepared DENA ( $200 \mathrm{mg} / \mathrm{kg} . \mathrm{bw})$, then two weeks later, they received subcutaneous injection of $\mathrm{CCL}_{4}$ once every week $(3 \mathrm{ml} / \mathrm{kg}$.bw)for 10 weeks to promote the carcinogenic effect of DENA.

Group-5-(HCC+BPA): Rats of this group treated with the same treatment of group 4, besides orally gavaged with bisphenol $\mathrm{A}$ as in group 3 for 15 weeks.

Group-6-(HCC+CIS): Rats of this group received the same treatment as described in group 4 then received an intraperitoneal injection of cisplatin $(1.5 \mathrm{mg} / \mathrm{kg}$.bw) repeated twice a week for 3 weeks.

Group-7-(HCC+BPA+CIS): Rats of this group were given the same treatment as described in group 5 and after 12 weeks were given an intraperitoneal injection of cisplatin $(1.5 \mathrm{mg} / \mathrm{kg} . \mathrm{bw})$ repeated twice a week for 3 weeks.

\section{Blood and tissue sampling}

At the final of the experimental period, animals were overnight fasted and sacrificed by cervical dislocation and blood samples were collected into non-heparinized tubes. After complete blood coagulation, the tubes were centrifuged at 3000rpm for $15 \mathrm{~min}$ then the separated sera were frozen at $-20^{\circ} \mathrm{C}$ for future biochemical analysis. Animals were dissected and liver tissues were isolated and cleaned. Some liver sections from each rats group were stored in neural formalin $10 \%$ for histopathological studies. Tissue samples from the same portion of the liver tissues were accurately weighted and homogenized in a 10 fold volume of an ice-cold sodium, potassium phosphate buffer $(0.01 \mathrm{M}, \mathrm{PH}$ 7.4) containing $1.15 \% \mathrm{KCL}$ in a potter-Elvehjem type homogenizer for later biochemical analysis.

\section{Biochemical analysis}

Serum ALT and AST activities were assayed by kinetic method according to Reitman and Frankel ${ }^{[5]}$. Alkaline phosphatase (ALP) activity was estimated in serum according to Belfield and Goldberg ${ }^{[6]}$.Total bilirubin content was 
estimated in serum according to Walter and Gerade ${ }^{[7]}$.Total protein content was estimated according to Henry ${ }^{[8]}$.Albumin content was estimated according to Doumas et al.. ${ }^{[9]}$ Quantitative determination of serum alpha fetoprotein (AFP) level was estimated by immunoenzymatic colorimetric method as described by Acosta. ${ }^{[10]}$.Serum tumor necrosis factor (TNF- $\alpha)$ was measured, using ELISA technique, that is a solid phase enzyme amplified sensitivity immunoassay according to Aggarwal ${ }^{[11]}$.Total lipids (TL) level in serum was estimated according to Zollner and Kirsch ${ }^{[12]}$. Total cholesterol in serum was estimated according to Allain et $\boldsymbol{a l} .{ }^{[13]}$.Triglycerides (TG) level in serum was estimated according to Fassati and Prencipe ${ }^{[14]}$.Serum high-density lipoprotein cholesterol (HDL-C) level was determined according to Lopez et al. ${ }^{[15]}$ Serum Low-density lipoprotein cholesterol (LDL-C) level was calculated according to Ahmedi et al. ${ }^{[16]}$, by the following equation: LDL-C=TC-HDL-C-TG/5.Serum very low-density lipoprotein (VLDL-C) Level was calculated by the following equation as described by Satheesh and Pari ${ }^{[17]}$ : VLDL-C $=$ TG/5. Hepatic contents of MDA according to Del Rio et al. ${ }^{[18]} \mathrm{GSH}$, SOD , CAT and GST according to the principle described by Sheehan $\boldsymbol{e t}$ al . ${ }^{[19]}$.Hepatic content of $\mathrm{H}_{2} \mathrm{O}_{2}$ was measured according to Votyakova and Reynolds ${ }^{[20]}$. The liver contents of p53, caspase-3 and Bcl-2 were quantitatively estimated using ELISA kits on basis of the procedure of Bennett et al. [21].

\section{Statistical analysis}

Data analysis were achieved by using graph pad prism software (V 5.02 Graph pad software Inc., La Jolla , CA)in which one-way ANOVA was used and followed by Tukey test at $\mathrm{P} \leq 0.05$.

\section{RESULTS \\ 1- Biochemical Results:}

Table 1 shows relative liver/body weight ratio, serum ALT, AST and ALP, serum total bilirubin, serum total protein and albumin, serum AFP and serum TNF- $\alpha$ in control and different treated rat groups. BPA, HCC and $\mathrm{HCC}+\mathrm{BPA}$ groups both showed an increase in relative liver/body weight ratio as well as, serum ALT, AST, ALP and total bilirubin especially the third one. While serum total protein and albumin showed a significant depletion in the three groups. Post treatment with cisplatin showed displayed amelioration in these parameters especially in HCC group which recorded a significant improvement more than that in $\mathrm{HCC}+\mathrm{BPA}$ group.

Table 2 shows serum TL, TC, TG, LDL, VLDL and HDL in control and different treated rat groups. $\mathrm{BPA}, \mathrm{HCC}$ and $\mathrm{HCC}+\mathrm{BPA}$ groups showed an elevation in TL, TC, TG, LDL and VLDL. While HDL groups recorded a significant decrease in serum HDL level in the three groups especially the third one. Treatment of HCC and HCC+BPA groups with cisplatin resulted in significantly an improvement in HCC group in serum TL, TC, TG, HDL, LDL and V-LDL more than that in HCC+BPA group .

Table 3 shows hepatic MDA, GSH, SOD, CAT, $\mathrm{H}_{2} \mathrm{O}_{2}$ and GST in control and different treated rats groups. The results illustrated an increase in tissue MDA and $\mathrm{H}_{2} \mathrm{O}_{2}$ in BPA, HCC and $\mathrm{HCC}+\mathrm{BPA}$ groups while GSH, SOD and GST showed a significant decrease in the three treated groups. After cisplatin treatment to HCC and $\mathrm{HCC}+\mathrm{BPA}$ there was amelioration in the two groups especially the first one.

Table 4 shows hepatic p53, caspase-3and Bcl2 in control and different treated rats groups. There was an elevation in hepatic p53 and caspase- 3 in BPA, HCC and HCC+BPA treated groups in contrary Bcl-2 level was depressed in the three groups. Post-treatment of the HCC and HCC+BPA groups with cisplatin showed an improvement in the three parameters in the two groups especially $\mathrm{HCC}$ treated group.

\section{2 - Histopathological results}

Light microscopic examination of sections from the liver of these groups showed the same structures, the normal histological picture of the liver was recorded. The hepatocytes $(\mathrm{H})$ are arranged in anastomosing plates radiating from the central veins $(\mathrm{CV})$. Blood sinusoids (BS) lined with endothelial cells (E) and Kupffer cells $(\mathrm{KC})$ are seen between the plates of hepatocytes (Figure A). In BPA treated group showed disarrangement of, a mass of mononuclear cellular infiltration (arrow), peripheral hepatocytes show ballooning and vacuolization with pyknotic nuclei (crossed arrows). The central veins are dilated and appear lost endothelial lining (asterisks) with congested 
blood sinusoids (arrow heads) (Figure B). Animals treated with DENA and $\mathrm{CCL}_{4}$ (HCC group) showed disarrangement of the hepatic strands. The central vein (CV) appears dilated and congested with disintegrated endothelial lining (arrows) and shrunken condensed nuclei (arrow heads) (Figure C). HCC+BPA group section showed a marked disorganization of hepatocytes with presence of thick connective tissue septa (arrow head) containing cellular infiltrate (arrow) and degenerated hepatocytes with dark nuclei (crossed arrows) are seen in the hepatic lobule (Figure D). Liver sections from $\mathrm{HCC}$ rats treated with cisplatin showed showing central vein $(\mathrm{CV})$, dilated congested blood sinusoids (arrows)between hepatic plates and some hepatocytes with dark nuclei (arrow heads) (Figure E).In $\mathrm{HCC}+\mathrm{BPA}+\mathrm{CIS}$ group the section showed disorganized hepatic lobules with evident septa in between (arrow), congested central veins are seen (arrow heads). The hepatocytes surrounding the central vein show ballooning and vacuolization (crossed arrows) (Figure F).

Table1: Effect of BPA on HCC and HCC+ CIS treated groups in Liver/body weight ratio, serum ALT, AST, ALP, total bilirubin, total protein and total albumin, AFP and TNF- $\alpha$.

\begin{tabular}{|c|c|c|c|c|c|c|c|}
\hline $\begin{array}{c}\text { Serum } \\
\text { parameters }\end{array}$ & $\mathbf{C}$ & Co & BPA & HCC & HCC+BPA & $\mathrm{HCC}+\mathrm{CIS}$ & $\mathrm{HCC}+\mathrm{BPA}+\mathrm{CIS}$ \\
\hline $\begin{array}{c}\text { Liver/body } \\
\text { weight ratio }\end{array}$ & $2.21 \pm 0.01$ & $2.10 \pm 0.03$ & $2.57 \pm 0.06^{a}$ & $3.22 \pm 0.1^{\mathrm{a}}$ & $3.89 \pm 0.04^{\mathrm{ab}}$ & $2.80 \pm 0.1^{\mathrm{ab}}$ & $3.55 \pm 0.1^{\mathrm{ac}}$ \\
\hline $\begin{array}{c}\text { ALT } \\
\text { (U/L) }\end{array}$ & $92.3 \pm 5.0$ & $93.8 \pm 6.5$ & $177.0 \pm 7.0^{\mathrm{a}}$ & $305.0 \pm 9.0^{\mathrm{a}}$ & $391.0 \pm 6.5^{\mathrm{ab}}$ & $228.7 \pm 16.3^{\text {ab }}$ & $348.5 \pm 5.0^{\mathrm{ac}}$ \\
\hline $\begin{array}{l}\text { AST } \\
(\mathbf{U} / \mathbf{L})\end{array}$ & $50.5 \pm 4.6$ & $52.0 \pm 6.4$ & $116.6 \pm 6.4^{a}$ & $321.1 \pm 18.3^{a}$ & $364.0 \pm 5.2^{\mathrm{ab}}$ & $242.5 \pm 8.3^{a b}$ & $292.0 \pm 9.8^{a c}$ \\
\hline $\begin{array}{l}\mathbf{A L P} \\
(\mathbf{U} / \mathbf{L})\end{array}$ & $201.2 \pm 7.7$ & $204.7 \pm 4.9$ & $231.9 \pm 5.5^{\mathrm{a}}$ & $369.7 \pm 6.8^{\mathrm{a}}$ & $405.2 \pm 7.9^{\mathrm{ab}}$ & $288.2 \pm 5.1^{\mathrm{ab}}$ & $333.2 \pm 12.7^{\mathrm{ac}}$ \\
\hline $\begin{array}{l}\text { Total bilirubin } \\
\text { (mg/dl) }\end{array}$ & $0.55 \pm 0.02$ & $0.52 \pm 0.01$ & $0.81 \pm 0.07^{a}$ & $1.64 \pm 0.02^{\mathrm{a}}$ & $1.97 \pm 0.03^{\mathrm{ab}}$ & $1.40 \pm 0.03^{\mathrm{ab}}$ & $1.78 \pm 0.02^{\mathrm{ac}}$ \\
\hline $\begin{array}{c}\text { Total protein } \\
(\mathrm{mg} / \mathrm{dl})\end{array}$ & $6.4 \pm 0.02$ & $6.5 \pm 0.02$ & $6.2 \pm 0.03^{\mathrm{a}}$ & $4.6 \pm 0.02^{a}$ & 4.4 $\pm 0.02 \mathrm{ab}$ & $5.6 \pm 0.03^{\mathrm{ab}}$ & $5.1 \pm 0.04^{\mathrm{ac}}$ \\
\hline $\begin{array}{c}\text { Total albumin } \\
(\mathrm{mg} / \mathrm{dl})\end{array}$ & $3.72 \pm 0.01$ & $3.77 \pm 0.02$ & $3.46 \pm 0.1^{\mathrm{a}}$ & $3.00 \pm 0.05^{\mathrm{a}}$ & $2.73 \pm 0.05^{\mathrm{ab}}$ & $3.37 \pm 0.1^{\mathrm{ab}}$ & $3.03 \pm 0.04^{\text {ac }}$ \\
\hline $\begin{array}{c}\text { AFP } \\
(\mathbf{n g} / \mathbf{m l})\end{array}$ & $0.62 \pm 0.02$ & $0.61 \pm 0.02$ & $1.55 \pm 0.09^{\mathrm{a}}$ & $2.45 \pm 0.03^{\mathrm{a}}$ & $3.67 \pm 0.02^{\mathrm{ab}}$ & $1.19 \pm 0.1^{\mathrm{ab}}$ & $2.91 \pm 0.1^{\mathrm{ac}}$ \\
\hline $\begin{array}{l}\text { TNF- } \alpha \\
\text { (pg/ml) }\end{array}$ & $0.125 \pm 0.01$ & $0.122 \pm 0.01$ & $0.185 \pm 0.01^{a}$ & $0.246 \pm 0.02^{a}$ & $0.269 \pm 0.02^{\mathrm{ab}}$ & $0.191 \pm 0.01^{\mathrm{ab}}$ & $0.238 \pm 0.01^{\text {ac }}$ \\
\hline
\end{tabular}

Letters $(a-b-c)$ express the significant change at $P \leq 0.05$ comparing to $(C),(H C C)$ and $(H C C+B P A)$ groups

respectively, values expressed as mean $\pm S E$ from 6 male rats in each group.

Table2: Effect of BPA on HCC and HCC+ CIS treated groups in Serum TL, TC, TG, LDL, V-LDL and HDL.

\begin{tabular}{|c|c|c|c|c|c|c|c|}
\hline $\begin{array}{c}\text { Serum } \\
\text { parameters }\end{array}$ & $\mathbf{C}$ & Co & BPA & HCC & HCC+BPA & $\mathrm{HCC}+\mathrm{CIS}$ & $\mathrm{HCC}+\mathrm{BPA}+\mathrm{CIS}$ \\
\hline $\begin{array}{c}\text { TL } \\
(\mathrm{mg} / \mathrm{dl})\end{array}$ & $413.2 \pm 11.2$ & $397.4 \pm 6.1$ & $486.8 \pm 11.5^{a}$ & $600.0 \pm 21.2^{a}$ & $684.3 \pm 12.7^{\mathrm{ab}}$ & $488.3 \pm 15.1^{\mathrm{ab}}$ & $615.2 \pm 18.4^{\mathrm{ac}}$ \\
\hline
\end{tabular}


Assessment the Role of Bisphenol A on Chemotherapeutic Efficacy of Cisplatin...

\begin{tabular}{|c|c|c|c|c|c|c|c|}
\hline $\begin{array}{c}\text { TC } \\
(\mathrm{mg} / \mathrm{dl})\end{array}$ & $80.1 \pm 2.4$ & $75.9 \pm 2.6$ & $94.8 \pm 2.3^{a}$ & $131.8 \pm 3.0^{a}$ & $148.5 \pm 3.7^{a b}$ & $106.2 \pm 1.7^{\mathrm{ab}}$ & $134.8 \pm 2.4^{\mathrm{ac}}$ \\
\hline $\begin{array}{c}\text { TG } \\
(\mathrm{mg} / \mathrm{dl})\end{array}$ & $54.4 \pm 0.8$ & $50.1 \pm 0.7$ & $89.2 \pm 3.0^{a}$ & $113.6 \pm 3.2^{a}$ & $132.5 \pm 2.2^{\mathrm{ab}}$ & $90.8 \pm 4.7^{\mathrm{ab}}$ & $115.3 \pm 5.2^{\mathrm{ac}}$ \\
\hline $\begin{array}{c}\text { LDL } \\
(\mathrm{mg} / \mathrm{dl})\end{array}$ & $29.9 \pm 0.1$ & $27.4 \pm 0.9$ & $43.6 \pm 0.9^{a}$ & $83.1 \pm 1.4^{\mathrm{a}}$ & $100.7 \pm 3.5^{\mathrm{ab}}$ & $62.0 \pm 2.4^{\text {ab }}$ & $88.0 \pm 1.4^{a c}$ \\
\hline $\begin{array}{l}\text { V-LDL } \\
\text { (mg/dl) }\end{array}$ & $10.8 \pm 0.6$ & $10.0 \pm 0.9$ & $17.8 \pm 0.7^{a}$ & $22.7 \pm 2.5^{a}$ & $26.5 \pm 2.8^{\mathrm{ab}}$ & $18.1 \pm 2.6^{a b}$ & $23.0 \pm 1.7^{a c}$ \\
\hline $\begin{array}{c}\text { HDL } \\
\text { (mg/dl) }\end{array}$ & $38.2 \pm 1.1$ & $41.5 \pm 0.8$ & $32.5 \pm 0.8^{a}$ & $24.9 \pm 1.3^{\mathrm{a}}$ & $20.5 \pm 0.8^{a b}$ & $31.1 \pm 0.7^{a b}$ & $24.4 \pm 0.5^{a c}$ \\
\hline
\end{tabular}

Letters $(a-b-c)$ express the significant change at $P \leq 0.05$ comparing to $(C)$, (HCC) and (HCC $+B P A)$ groups respectively, values expressed as mean $\pm S E$ from 6 male rats in each group.

Table3: Effect of BPA on HCC and HCC+ CIS treated groups in hepatic MDA, $\mathrm{H}_{2} \mathrm{O}_{2}, \mathrm{GSH}, \mathrm{CAT}$, SOD and GST.

\begin{tabular}{|c|c|c|c|c|c|c|c|}
\hline $\begin{array}{c}\text { Tissue } \\
\text { parameters }\end{array}$ & $\mathrm{C}$ & Co & $\overline{\text { BPA }}$ & HCC & HCC+BPA & $\mathrm{HCC}+\mathrm{CIS}$ & $\mathrm{HCC}+\mathrm{BPA}+\mathrm{CIS}$ \\
\hline $\begin{array}{c}\text { MDA } \\
(\mathrm{nmol} / \mathrm{mg})\end{array}$ & \begin{tabular}{|c|c|}
$0.173 \pm 0.001$ \\
\end{tabular} & $0.174 \pm 0.002$ & $0.215 \pm 0.003^{a}$ & $0.237 \pm 0.008^{a}$ & $0.250 \pm 0.004^{\mathrm{ab}}$ & $0.198 \pm 0.010^{\mathrm{ab}}$ & $0.224 \pm 0.002^{\mathrm{ac}}$ \\
\hline $\begin{array}{c}\mathrm{H}_{2} \mathrm{O}_{2} \\
(\mathrm{Pmol} / \mathrm{mg})\end{array}$ & $0.131 \pm 0.001$ & $0.132 \pm 0.001$ & $0.155 \pm 0.002^{a}$ & $0.187 \pm 0.01^{a}$ & $0.215 \pm 0.003^{a b}$ & $0.156 \pm 0.01^{a b}$ & $0.191 \pm 0.003^{a c}$ \\
\hline $\begin{array}{c}\text { GSH } \\
(\mathrm{mg} / \mathrm{g})\end{array}$ & $0.301 \pm 0.003$ & $0.303 \pm 0.003$ & $0.256 \pm 0.001^{a}$ & $0.239 \pm 0.003^{a}$ & $0.212 \pm 0.003^{\text {ab }}$ & $0.272 \pm 0.002^{\mathrm{ab}}$ & $0.233 \pm 0.01^{\text {ac }}$ \\
\hline $\begin{array}{l}\text { SOD } \\
\text { (U/g) }\end{array}$ & $0.204 \pm 0.01$ & $0.203 \pm 0.01$ & $0.184 \pm 0.01^{a}$ & $0.147 \pm 0.02^{a}$ & $0.126 \pm 0.03^{a b}$ & $0.173 \pm 0.02^{a b}$ & $0.141 \pm 0.01^{\text {ac }}$ \\
\hline $\begin{array}{c}\text { CAT } \\
(\mu \mathrm{mol} / \mathrm{g})\end{array}$ & \begin{tabular}{|l|}
$0.258 \pm 0.001$ \\
\end{tabular} & $0.256 \pm 0.001$ & $0.228 \pm 0.004^{a}$ & $0.184 \pm 0.004^{a}$ & $0.143 \pm 0.001^{a b}$ & $0.213 \pm 0.004^{\mathrm{ab}}$ & $0.156 \pm 0.002^{\mathrm{ac}}$ \\
\hline $\begin{array}{c}\text { GST } \\
(\mathrm{mmol} / \mathrm{g})\end{array}$ & 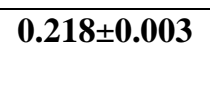 & $0.224 \pm 0.01$ & $0.187 \pm 0.002^{a}$ & $0.149 \pm 0.01^{a}$ & $0.118 \pm 0.001^{a b}$ & $0.184 \pm 0.01^{a b}$ & $0.136 \pm 0.003^{\mathrm{ac}}$ \\
\hline
\end{tabular}

Letters $(a-b-c)$ express the significant change at $P \leq 0.05$ comparing to $(C),(H C C)$ and $(H C C+B P A)$ groups respectively, values expressed as mean \pm SE from 6 male rats in each group.

Table4: Effect of BPA on HCC and HCC+ CIS treated groups in hepatic p53, caspase-3 and Bcl-2.

\begin{tabular}{|c|c|c|c|c|c|c|c|}
\hline $\begin{array}{c}\text { Tissue } \\
\text { parameters }\end{array}$ & $\mathrm{C}$ & Co & BPA & HCC & $\mathrm{HCC}+\mathrm{BPA}$ & $\mathrm{HCC}+\mathrm{CIS}$ & $\begin{array}{c}\mathrm{HCC}+\mathrm{BPA}+\mathrm{CI} \\
\mathrm{S}\end{array}$ \\
\hline $\begin{array}{c}\text { p53 } \\
(\mathrm{pg} / \mathrm{mg})\end{array}$ & $\begin{array}{c}0.109 \pm 0.00 \\
2\end{array}$ & $\begin{array}{c}0.108 \pm 0.00 \\
2\end{array}$ & $0.193 \pm 0.04^{a}$ & $0.241 \pm 0.01^{\mathrm{a}}$ & $\underset{b}{0.262 \pm 0.01^{a}}$ & $\begin{array}{c}0.184 \pm 0.06 \\
b\end{array}$ & $0.213 \pm 0.01^{\mathrm{ac}}$ \\
\hline $\begin{array}{l}\text { caspase-3 } \\
(\mathrm{ng} / \mathrm{mg})\end{array}$ & $\begin{array}{l}0.135 \pm 0.00 \\
3\end{array}$ & $\begin{array}{l}0.130 \pm 0.00 \\
3\end{array}$ & $0.151 \pm 0.04^{a}$ & $\begin{array}{l}0.193 \pm 0.002 \\
\text { a }\end{array}$ & $\begin{array}{l}0.209 \pm 0.01^{\mathrm{a}} \\
\mathrm{b}\end{array}$ & $\begin{array}{l}0.160 \pm 0.01^{a} \\
b\end{array}$ & $0.185 \pm 0.06^{a c}$ \\
\hline $\begin{array}{l}\text { Bcl-2 } \\
\text { (U/g) }\end{array}$ & $\begin{array}{l}0.258 \pm 0.00 \\
2\end{array}$ & $\begin{array}{l}0.256 \pm 0.00 \\
2\end{array}$ & $0.224 \pm 0.005^{a}$ & $\begin{array}{l}0.196 \pm 0.005 \\
\text { a }\end{array}$ & $\begin{array}{l}0.163 \pm 0.003 \\
\text { ab }\end{array}$ & $\begin{array}{l}0.230 \pm 0.01^{a} \\
b\end{array}$ & $0.186 \pm 0.004^{a c}$ \\
\hline
\end{tabular}

Letters $(a-b-c)$ express the significant change at $P \leq 0.05$ comparing to $(C),(H C C)$ and $(H C C+B P A)$ groups respectively, values expressed as mean $\pm S E$ from 6 male rats in each group.

Figure A-F: Histopathological changes of liver sections stained with hematoxylin and eosin staining. 

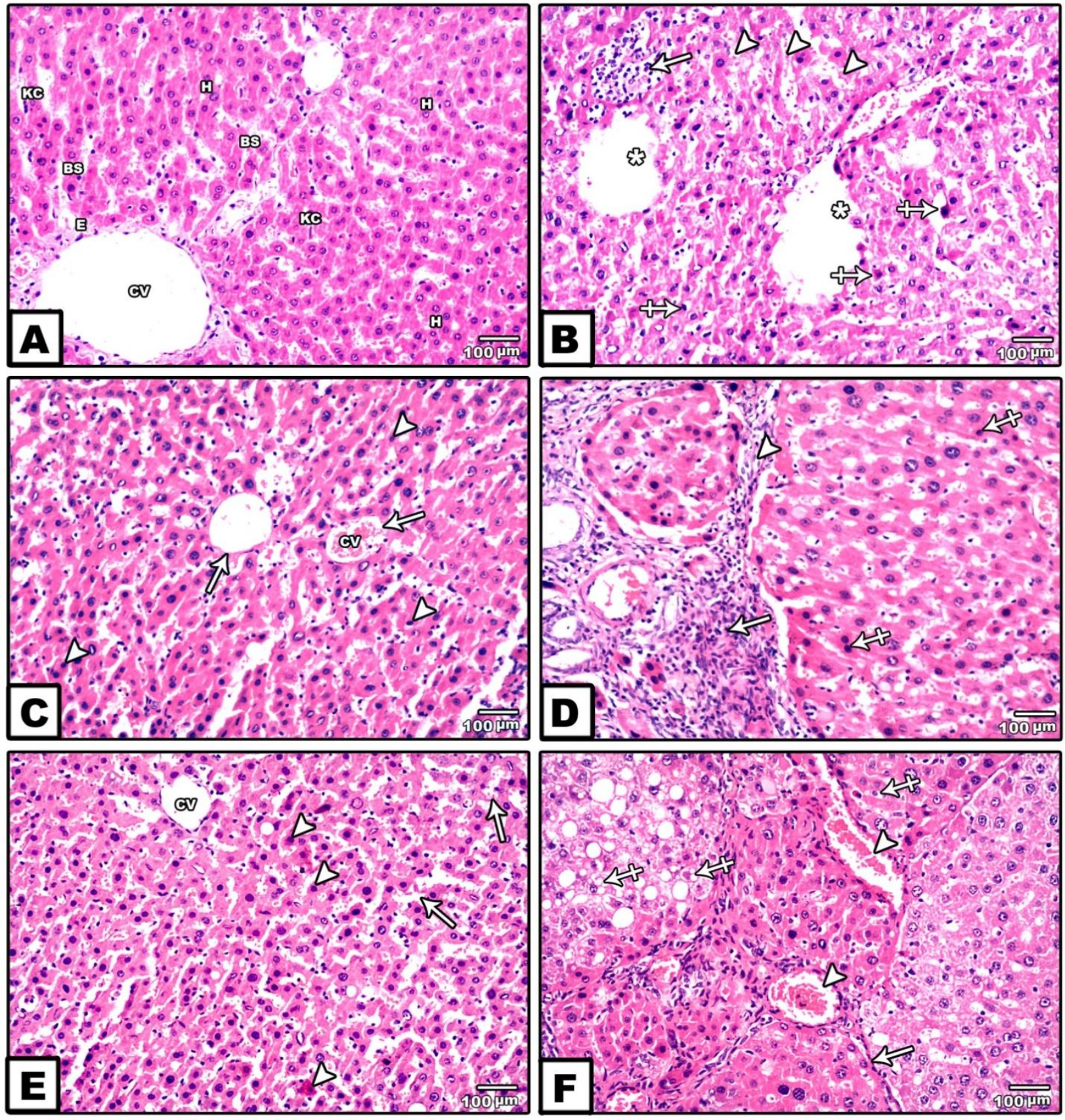

(Fig .A): A paraffin section of $C$ group, the hepatocytes $(H)$ is arranged in anastomosing plates radiating from the central veins $(C V)$. Blood sinusoids (BS) lined with endothelial cells $(E)$ and Kupffer cells $(K C)$ are seen. (H\&E, X100).(Fig .B): BPA group showing a mass of infiltration (arrow), peripheral hepatocytes show ballooning and vacuolization with pyknotic nuclei (crossed arrows). The central veins are dilated and appear lost endothelial lining (asterisks) with congested blood sinusoids (arrow heads). (H\&E, X100).(Fig .C): A section of group HCC. The central vein (CV) appears dilated and congested with disintegrated endothelial lining (arrows) and shrunken condensed nuclei (arrow heads). (H\&E, X100).(Fig .D): A paraffin section group HCC+BPA showing marked disorganization of hepatocytes with presence of thick connective tissue septa (arrow head) containing cellular infiltrate (arrow) and degenerated hepatocytes with dark nuclei (crossed arrows) are seen in the hepatic lobule. (H\&E, X100).(Fig. E): HCC+CIS group showing central vein (CV), dilated congested blood sinusoids (arrows) between hepatic plates and some hepatocytes with dark nuclei (arrow heads). (H\&E, X100) '

\section{DISCUSSION}

Several studies demonstrated the toxicity of bisphenol A (BPA) even at low doses. Moreover other studies have shown that BPA can cause injury in the liver, kidney, brain and other rodent organs by forming reactive oxygen species (ROS). Oxidative stress can lead to chronic 
inflammation, which in turn could mediate most chronic diseases including cancer, diabetes and cardiovascular, neurological and pulmonary diseases [22]. Resistance to chemotherapeutic drugs is frequently encountered problem in the treatment of human cancers. The current study revealed that BPA confer resistance to apoptosisinducing chemotherapy by preventing the activation of caspase- 3 which considered as the executioner of the apoptosis process.

Among carcinogenic compounds, diethylnitrosamine (DENA) is well known as a tumor initiator, which used in experimental rodent models of HCC. However, the carcinogenic capacity of DENA is situated in its capability of inducing oxidative stress and alkylating DNA structure. Alkylation of DNA, ROS and free radicals results from P450dependent enzymatic system, namely, CYP2E1, might induce oxidative stress by the formation of hydrogen peroxide and superoxide anions [23]. ROS are familiar for interacting and inducing damages at different levels, for example, cellular protein, lipids, and DNA, causing cellular dysfunction. Therefore, oxidative stress is largely known as a key player in hepatocarcinogenesis, both at initiation and progression stages. On the other hand, $\mathrm{CCl}_{4}$ which is a non-genotoxic carcinogen has no direct interaction with DNA and is one of the potent hepatotoxins that have been known as tumor promoters. $\mathrm{CCl}_{4}$ metabolism starts with the trichloromethyl free radical $(. \mathrm{CCl} 3)$ by the activity of the mixed function of the cytochrome P450 oxygenase system. Very rapidly this free radical reacts with oxygen to produce a highly radicals are capable of bounding to proteins or lipids, thus initiating lipid peroxidation ${ }^{[24]}$. Lipid peroxidation may cause peroxidative tissue damage and inflammation. Lipid peroxidation increased level products play a principle role in hepatotoxicity. Izzotti et al. ${ }^{[25]}$ confirmed the capability of BPA to form DNA adducts both in vitro and in vivo in rodent liver. BPA is transformed to bisphenol Oquinone which might be the final DNA binding metabolite .This binding might prevent RNA polymerase from transcribing the DNA and can inhibit the protein synthesis, which may be considered to be the cause of the liver cell necrosis.
Our results revealed a significant increase in relative the liver weight in the DENA and $\mathrm{CCl}_{4}$ treated rats group. This increase in relative liver weight might be due to hyperplasia, hypertrophy and induction of liver cirrhosis by DENA. Similarly, in another survey of mouse national toxicology program (NTP) studies correlations between liver weight increases and histological parameters and carcinogenesis were assessed, the authors concluded that "the best single predictor of liver cancer in mice was hepatocellular hypertrophy" [26]. BPA was found also to increase liver/body weight ratio, Abdel-Wahab ${ }^{[27]}$ mentioned that liver enlargement may be due to a combination of hepatocyte hypertrophy and smooth endoplasmic reticulum proliferation which is presumed to stimulate a hepatic physiology adaptation to an increased workload demand. Post-treatment with cisplatin caused apparent improvement in liver/body weight ratio; our results were in accordance with the experimental studies conducted by Lee $\boldsymbol{e t}$ al. ${ }^{[28]}$, who indicated that cisplatin treatment for 15 days in BALB/C mice resulted in liver weight loss.

Our study revealed a significant increase in the serum liver marker enzymes, AST, ALT and ALP in BPA, HCC and HCC+BPA groups while post-treatment with CIS showed significant decreases in their levels in $\mathrm{HCC}+\mathrm{CIS}$ and less amelioration in $\mathrm{HCC}+\mathrm{BPA}+\mathrm{CIS}$ group. In agreement with our results, several research groups revealed these enzymes elevation in HCC. When the liver hepatocytes are damaged, these enzymes are liberated into the blood where the significant increase in AST and ALT activities indicates the damage to the cytosol and also to mitochondria. BPA was found to increase oxidative stress and inhibit cellular antioxidant activity. This elevation in oxidative stress leads to an increase in the hepatic oxidative stress, mitochondrial dysfunction and hepatotoxicity leading to structural changes and cellular damage of rat liver which as a result increase ALT and AST levels in serum. Comparable study reported an increase in the serum ALT and AST levels in BPA group compared to the control one. The tumor development results in tissue damage that leads to ALP release into circulation in the tumorbearing animals. ALP elevation is one of the signs suggesting space-occupying lesions in the liver. 
In addition, there was an observed elevation in serum bilirubin level in BPA, HCC and HCC+ BPA groups. Liver dysfunction is reflected by elevation in serum bilirubin concentration. In agreement with our results Gnanaraja and Prakash, [29], found that tumor bearing mice showed a significant increase in serum bilirubin level. This high concentration of serum bilirubin may be due to an increased degeneration rate of red blood cells. The increased levels of serum bilirubin in BPA as well as HCC+BPA may suggest that BPA might act as a plasma membrane labilizer. This result is in agreement with previous study with similar increase in serum bilirubin level ${ }^{[27]}$. The data showed also a reduction in total protein and albumin in BPA, $\mathrm{HCC}$ and $\mathrm{HCC}+\mathrm{BPA}$ rats groups. The lower level of total protein is a signal of reduction in the biosynthesis of proteins which may be due to destruction and dissociation of polyribosomes on the endoplasmic reticulum as a consequence of DENA toxicity. BPA may either act by activating or inhibiting enzyme activities in the cell or destruction of the cell organelles with liberation of particular enzymes is one of the reasons to alter the expression of total proteins and another reason is oxidative stress influenced by excess ROS produced in mitochondria and microsomes in cells are known to damage proteins. Consequently, the decrease in albumin level may be associated with liver disease. In cisplatintreated rats groups, present results exhibited a significant amelioration in serum ALT, AST, ALP, total protein and albumin in $\mathrm{HCC}+\mathrm{CIS}$ as well as in $\mathrm{HCC}+\mathrm{BPA}+\mathrm{CIS}$ group. This cisplatin effect is compatible with available data reported by ${ }^{[1]}$.

In support to previous estimated parameters our results showed elevated serum AFP and TNF$\alpha$ levels in BPA, HCC, HCC+BPA rats group with a significant expression in $\mathrm{HCC}+\mathrm{BPA}$ group. In addition, $\mathrm{HCC}+\mathrm{BPA}+\mathrm{CIS}$ group shows significantly high serum AFP and TNF- $\alpha$ level than HCC+CIS group. It was found that, HCC and chronic liver disease, strongly correlates with $\alpha$-fetoprotein elevation up to the pathological range. The difference in AFP level in the two treated groups was also clear as $\mathrm{HCC}+\mathrm{CIS}$ rats group was more responded to CIS treatment, in agreement Bialecki and Di-Biscegline [30], reported such result, as AFP levels were also shown to mirror tumor responsiveness to nonsurgical therapies for HCC such as chemotherapy and it was detected the benefit use of AFP during monitoring of liver cancer treatment which is well accepted in patients with increased AFP levels before therapy. Our results also recorded a significant elevation in serum TNF- $\alpha$ in BPA treated group when compared to control one. This elevation may be due to the hepatic inflammatory response which is mediated by proinflammatory cytokines, especially TNF- $\alpha$, its release considered as one of the first events in many types of liver injury. In agreement, previous study has shown a significant correlation between BPA and inflammatory markers such as TNF- $\alpha$. Previous study reported, the upregulated of hepatic expression of TNF- $\alpha$ in $\mathrm{HCC}{ }^{[31]}$. The present data also recorded a significant improvement in serum TNF- $\alpha$ in $\mathrm{HCC}+\mathrm{CIS}$ than that in $\mathrm{HCC}+\mathrm{BPA}+\mathrm{CIS}$ rats group. This may be due to, markedly decreased serum TNF- $\alpha$ concentration during chemotherapy, this was confirmed in several studies in breast and prostate cancer patients and the extent of serum TNF- $\alpha$ concentration was well-correlated with the extent of therapy responses, suggesting that serum TNF- $\alpha$ level could be an indicator for chemotherapy response and prognosis.

In this study the occurred alternation in lipid profile reported in BPA, HCC and $\mathrm{HCC}+\mathrm{BPA}$ rat groups with a significantly more elevated level in the third one, this may be due to DENA induced abnormal lipid synthesis or defective degradation of lipids and then implicated in a pathological condition like cancer. HCC development has also been associated with disorders in plasma lipid and lipoprotein metabolism. In addition, BPA has been found to stimulate lipid accumulation and up-regulate genes involved in lipid metabolism in adipocytes. This disturbance may be due to, the estrogenic activity induced by BPA, which is a well-known endocrine-disrupting chemical that binds to estrogen receptors and results in competition with estrogen and disrupting the lipid profile, it is manifested through an increase in LDL cholesterol and a decrease in HDL cholesterol. Treatment with CIS caused an improvement in the levels of serum TL, TC and $\mathrm{TG}$, as well as, the obtained data showed a significant amelioration in HDL-C, LDL-C and 
VLDL-C in cisplatin- treated rats. This result appeared to be compatible with the data reported by ${ }^{[31]}$.

In the present study there was an increase in MDA and $\mathrm{H}_{2} \mathrm{O}_{2}$ levels and a reduction in GSH, CAT, SOD and GST activities in BPA, HCC and $\mathrm{HCC}+\mathrm{BPA}$ rats groups, this unbalance may be due to peroxidation process. Many reactive aldehydes, such as MDA which is a major end product of lipid peroxidation which can crosslink with DNA and other protein molecules, thereby it promotes tumorigenesis .MDA owing to its cytotoxicity and inhibitory action on cellular protective enzymes is suggested to act as a tumor promoter and a carcinogen agent. Previous reports manifested an increase in lipid peroxide formation, cell membrane damage and decreased levels of antiperoxidative enzymes after DENA treatment. Korkmaz et al. ${ }^{[32]}$ showed an increase in MDA level in the liver of rats exposed to BPA. This elevation in MDA levels could be due to ROS overproduction and antioxidant enzymes levels suppression resulting in the altered redox potential of cell causing lipid peroxidation and cell damage. In consistent several studies recorded the incidence of oxidative toxicity after BPA exposure in rats and mice.

The present study also reported a significant alternation in antioxidant defense system in BPA, $\mathrm{HCC}$ and $\mathrm{HCC}+\mathrm{BPA}$ rats groups. The levels of non-enzymatic antioxidant like GSH were decreased in serum and tissues of DENAadministered rats. The decrease in GSH content in circulation has been reported in malignant states which may contribute to increased susceptibility to lipid peroxidation. GSH content was significantly reduced due to BPA administration, which could be explained by the increased consumption of GSH in scavenging the BPA-generated ROS .The reduction in SOD and CAT activities was demonstrated in our results in $\mathrm{HCC}$ and BPA+HCC which may be due to their function in detoxifying mechanisms by transforming superoxide anion and $\mathrm{H}_{2} \mathrm{O}_{2}$ into $\mathrm{O}_{2}$ and $\mathrm{H}_{2} \mathrm{O}$, respectively. In agreement, EL Shahat ${ }^{[33]}$ suggests inactivation of the enzyme possibly due to elevated superoxide radical production or an inhibition by the $\mathrm{H}_{2} \mathrm{O}_{2}$ as a result of corresponding decrease in the activity of CAT which selectively degrades $\mathrm{H}_{2} \mathrm{O}_{2}$. In addition, these significant reduced activities of antioxidant enzymes CAT, SOD and GST in BPA as well as $\mathrm{HCC}+\mathrm{BPA}$ rats groups might be due to BPA induction of protein oxidation. Lipid peroxidation products interaction with enzyme molecules leads to the exclusive modification of histidine residue and generation of protein-protein cross linked derivatives causing reduction in enzyme activity. These results in agreement with previous study reported this reduction in their activities in male mice and rats livers when exposed to BPA ${ }^{[34]}$. GST protects cells or tissues against oxidative stress and damage by detoxifying various toxic substrates derived from cellular oxidative processes. In agreement with our results previous study suggested that high dose of BPA not only elevates the free radical formation but also reduces GST ability to detoxify ROS.

An improvement in MDA and $\mathrm{H}_{2} \mathrm{O}_{2}$ levels and GSH, SOD, CAT and GST activities after cisplatin treatment were observed in our results. This improvement may be due to regenerative responses of the liver which naturally occurs after chemicals administration or viruses' injury, in addition to the regenerative signaling pathways multiple inflammatory signaling pathways also work in the case of removing injured hepatic tissue before the initiation of regeneration. After hepatocyte necrosis, polymorphonuclear leukocytes and macrophages perform infiltration of the affected areas, resulting in removal of the dead cells. Liver regeneration is elucidated by entry into DNA synthesis of hepatocytes of the unaffected areas of the lobule. Gene expression patterns of hepatocytes in the repaired areas of the lobule return to that of the normal liver soon thereafter. Another pattern of the regeneration during which all hepatocytes are hurt, oval cells which is potent stem cells differentiate into hepatocytes and biliary cells. These results are in harmony with others ${ }^{[31][1]}$ who demonstrated the improvement in MDA and $\mathrm{H}_{2} \mathrm{O}_{2}$ levels and $\mathrm{GSH}$, SOD, CAT and GST activities after cisplatin treatment.

The present study also demonstrated a significant over-expression levels of p53 and caspse-3 and down-regulation of anti-apoptotic marker, Bcl-2 level in BPA, as well as HCC and $\mathrm{HCC}+\mathrm{BPA}$ while post-treatment of the last two groups with cisplatin showed an improvement in these parameters with a highly percentage of amelioration in HCC group more than that in 
$\mathrm{HCC}+\mathrm{BPA}+\mathrm{CIS}$ group .In the case of BPA the possible explanation for this over-expression may be due to metabolism of BPA which mainly occurs in the liver. BPA is glucuronidated by liver microsomes. Glucuronidation process is mediated by UGT2B1, an isoform of UGT in rat liver. The microsomal Cytochrome P450s produced BPA metabolites which showed estrogenic activity such as DNA adducts formation with BPA metabolites. Another mechanism for SOD induced apoptosis is through its ability to activate p53 by production of $\mathrm{H}_{2} \mathrm{O}_{2}$. The achievement of apoptosis is performed by a family of aspartate-specific cysteine proteases that cleave their substrate and then activate caspases cascade. The current study revealed that exposure of rats to BPA was found to increase caspase-3 levels in the liver tissue of the rats as compared to the normal control group. This may be due to that caspases are proteases activated after a cell has received a signal ordering it to undergo apoptosis. BPA may cause a reduction in the Bcl-2 level and activates caspase- 3 which may be due to BPA could faster increased DNA damage, and genotoxicity is by the inhibition of cellular antioxidant activity and increase the oxidative stress. Cellular levels of the tumor suppressor p53 are normally low, but this increase may be due to inactivated $\mathrm{p} 53$ by a single point mutation, and in others, the p53 protein is expressed at normal levels but the signaling pathways that lead to cell cycle arrest and apoptosis are defective. In addition, previous researches have reported p53 mutations and its inactivation in HCC.

Additionally, the occurred increased caspase-3 in HCC rat groups may be due to associated with high serum levels of AFP.Caspase-3 overexpression may serve as a diagnostic and therapeutic marker for HCC. Although more than a dozen of caspases have been identified up-to date, caspase-3 stands out because it is commonly activated in response to various death stimuli. The overexpression of caspases in many cell types induces apoptosis, whereas inhibition of caspase activity has the opposite effect, showing that these enzymes are a remarkable mediator of apoptosis. As mentioned above, p53 is a noticeable apoptosis-regulating gene, it was reported that p53 serves as a very important regulator Bax pathway, it also causes down regulation of $\mathrm{Bcl}-2$. Parallel with that, there is evidence of elevated apoptosis in HCC induced by DENA of rats accompanied with p53 overexpression and decreased $\mathrm{Bcl}-2$.

Post-treatment of HCC and HCC+BPA with cisplatin resulted in amelioration in $\mathrm{p} 53$, caspase3 and Bcl-2 levels. This improvement in HCC+CIS was reported in other research by Hemieda et al. ${ }^{[1]}$. The second treated group HCC+BPA+CIS manifested a less percent of improvement in these apoptotic parameters this may be due to, the ability of BPA to generate reactive oxygen species (ROS) by decreasing the activities of antioxidant enzymes and increasing lipid peroxidation, thereby causing oxidative stress in the rats liver. The consequence of lipid peroxidation products breaking down is the formation of many reactive aldehydes. Apoptosis can be triggered by oxidative stress through inducing damage to cellular components (e.g., DNA), and some researchers suggest that ROS are downstream mediators of apoptosis. In contrast to oxidative stress-induced apoptosis, excessive oxidative stress inhibits caspase activity, and drug-induced apoptosis, thereby conflicting with the ability of antineoplastic agents like cisplatin to kill tumor cells. Anticancer effects induced by various chemotherapeutic agents are considered to be based on induction of apoptosis and to be mediated through a final common pathway: activation of caspase-3 and subsequent DNA fragmentation. Recent studies suggest that caspase-3 plays an important role in several key events during apoptosis, such as nuclear fragmentation and DNA fragmentation. Caspase family members have been found in the cytosol as zymogens, and cleavage of procaspase- 3 to generate fragments is believed to be an indicative of commitment to apoptosis. The cleavage of procaspase- 3 is an early step in apoptosis, and this cleavage is induced by chemotherapeutic agents. When aldehydes bind to the nucleophilic groups of the amino acids, such as cysteine residue which are critical components of enzyme active site of caspases, this binding of aldehydes results in enzyme inhibition and an alteration of the structure of the cellular receptors and inhibit their activity. This result is in agreement with Lee and Shacter. ${ }^{[35]}$ who reported caspases inhibition after aldehyde generation which may interpret the 
reduced antineoplastic agent's efficacy during excessive oxidative stress .

Liver sections from control rats appear with normal liver histology, as they showed normal hepatic architecture, central vein (CV), hepatocyte $(\mathrm{H})$, blood sinusoids (BS). While most BPA liver sections revealed swollen and vacuolated hepatocytes (V) with nuclear degenerations, dilatation and congestion in the blood sinusoids (BS) . In addition, congestion of the portal vein and dilatation with periportal infiltration of inflammatory cells and mild fibrosis were observed. Moreover, HCC liver sections showed hydropic degeneration and focal areas of necrosis, portal inflammation, and hepatocytes showed partial loss of architecture. Both of the two treatment groups especially HCC+CIS showed histopathological and architecture improvement.

In conclusion, obtained data showed that exposure of adult male rats and $\mathrm{HCC}$ rats to high dose of BPA $322 \mathrm{mg} / \mathrm{kg} . b w$ orally has a deleterious effect especially on the HCC rats. BPA generates ROS, thereby causing oxidative stress in the liver of rats. These results are evidenced by the recorded abnormalities in the investigated biochemical parameters. BPA confer chemoresistance to cisplatin, possibly by preventing the activation of caspase-3.

\section{References:}

1. Hemieda F, Serag H, El-Baz E, Ramadan $S$ (2016): Therapeutic efficacy of licorice and/or cisplatin against diethylnitrosamine and carbon tetrachloride-induce hepatocellular carcinoma in rats. J. Am. Sci., 12: $10-19$.

2. Subramanian P, Mirunalini S, Dakshayani K et al. (2007): Prevention by melatonin of hepatocarcinogenesis in rats injected with $\mathrm{N}$ nitrosodiethylamine. J. Pineal. Res., 43: 305317.

3. Eladak S, Grisin T, Moison D, Guerquin $M$ et al.(2015): A new chapter in the bisphenol Astory: bisphenol S and bisphenol $\mathrm{F}$ are not safe alternatives to this compound. Fertil. Steril. 103: 11-21.

4. Kabuto $H$, Hasuike $S$, Minagawa $N$ and Shishibori T (2003): Effects of bisphenol A on the metabolisms of active oxygen species in mouse tissues. Int. J. Environ. Res., 93: 31-35.
5. Reitman J, Nilsson J, Tornvall $\mathbf{P}$, Landou $C$ and Hamsten A (1992): susceptibility to low-density lipoprotein oxidation and coronary atherosclerosis in man. Lancet, 339:1183-1186.

6. Belfield A and Goldberg D M (1971): Normal ranges and diagnostic value of serum 5, nucleotidase and alkaline phosphatase activities in infancy. Arch .Dis. Child, 46:864-846.

7. Walter $M$ and Gerade $H$ (1970): Colorimetric method for total bilirubin. Microchem. j., 15: 231-236.

8. Henry R J (1964): Determination of total protein by colorimetric Method. Clin. Chem., 3:181-182.

9. Doumas B T, Waston W A and Biggs H G (1971): Albumin standards and the measurement of serum albumin with bromcresol green. Clin. Chem. Acta ., 31 (1):87-96.

10. Acosta A (1983): Direct immunoenzymatic determination of AFP in serum or plasma. J. Clin, immunoassays, 6:41.

11. Aggarawal B B (1985): Human tumor necrosis factor production, purification and characterization. J. Bio. Chem., 260: 23452354.

12. Zollner $N$ and Kirsch $K$ (1962): Determination of the total lipid concentration in serum. Zentrabl Ges. Exp. Med., 135:454561.

13. Allain C , Poon L, Chan C et al. (1974): enzymatic determination of total serum cholesterol. Clin. Chem., 20:470-475.

14. Fassati $P$ and Prencipe L (1982): "erum triglycerides determined colorimetrically with an enzyme that produces hydrogen peroxide. Clin.Chem., 28:2077-2080.

15. Lopez and Virella M F (1977): Enzymatic colorimeteric method for determination of HDL. Clin. Chem., 23(5):882-884.

16. Ahmedi $S$ A, Borou-Mand $M A$, Moghddam K et al. (2008): he impact of low serum triglyceride on LDL cholesterol estimation. Arich. Iranian Med., 11:318-321.

17. Satheesh M and Pari L (2008): Effect of pterostillbene on lipids and lipid profiles in streptozotocin-nicotinamide induced type 2 diabetes mellitus. J. Appl. Biomed., 6:31-37. 
18. Del Rio D, Stewart A J and Pellegrini N (2005): A review of recent studies on malondialdehyde as toxic molecule and biological marker of oxidative stress .Nitr. Metab. Cardiovas. Dis., 15(4):316-328.

19. Sheehan D, Meadde $G$ and Foley V M (2001): structure, function and evolution of glutathione transferase: implications for classification of non-mammalian members of an ancient enzyme superfamily. Biochem. J., 360(1):1-16.

20. Votyakova $T \quad V$ and Reynolds $I \quad J$ (2004):https://www.journals.elsevier.com/ar chives-of-biochemistry-and-biophysics

21. Bennett M, Macdonald $K$, Chan $S$ et al. (1998): Cell surface trafficking of Fas: a rapid-mechanism of p53-mediated apoptosis.Sci., 282 (5387):290-293.

22. Kamp D V, Shacter E and Weitzman S A (2011): Chronic inflammation and cancer: the role of the mitochondria. Oncol., 25(5): 400-413.

23. Patterson J, Boateng J, Walker $L T$ and Verghese M (2012): Cytotoxic effects of multiple N-nitrosamines in human liver cell line Hep2G: possible mechanisms of action. J. Pharmacol. Toxicol ., 7(3): 114-127.

24. El-Sayed E, Fouda E, Mansour A and Elazab A (2015): Protective Effect of Lycopene against Carbon TetrachlorideInduced Hepatic Damage in Rats. Int. J. Pharma. Sci., 5(1): 875-881.

25. Izzotti A, Kanitz S, D'Agostini F, Camoirano A and De Flora $S$ (2009): Formation of adducts by bisphenol A, an endocrine disruptor in DNA in vitro and in liver and mammary tissue of mice. Mutation Res., 679:28-32.
26. Allen D, Pearse G, Haseman $J$ and Maronpot R (2004): Prediction of rodent carcinogenesis: An evaluation of prechronic liver lesions as forecasters of liver tumors in ntp carcinogenesis studies. Toxicol. Pathol ., 32: 393-401.

27. Abdel-Wahab W (2014):Thymoquinone attenuates toxicity and oxidative stress induced by bisphenol-A in liver of male rats. Paki. J. Biol. Sci., 1028-8880.

28. Lee C, Park K, Lim S et al. (2007): Effects of the licorice extract against tumor growth and cisplatin-induced toxicity in a mouse xenograft model of colon cancer .Biol. pharm. Bull., 30:2191-2195.

29. Gnanaraja $R$ and Prakash V (2014): Preventive Effect of tephrosia purpurea against N, N-diethylnitrosamine induced hepatocellular carcinoma in swiss albino mice. JBLS., 5(2).

30. Bialecki E S and Di-Biscegline A M (2005): Diagnosis of hepatocellular carcinoma. HPB., 7: 26-34.

31. Hassan H, Serag $H$, Abdel-Hamid $N$ and Amr M (2015): Synergistic curative effect of chicory extract and cisplatin against thioacetamide-induced hepatocellular carcinoma. Hepatoma Res., 1:147-54.

32. Korkmaz A, Ahbab M A, Kolankaya D and Barlas N (2010): Influence of vitamin c on bisphenol-A, nonylphenol and octylphenol induced oxidative damages in liver of male rats. Food chem. Toxical., 48:2865-2871.

33. El shahat A N (2013): Efficiency of broccoli in attenuating of some biochemical diorders in rats exposed to $\gamma$-irradiation. Arab. J. Sci. Applic., 46(4):260-567.

34. Hassan Z K, El obeid M A, Virk P S A et al. (2012): Bisphenol a induces hepatotoxicity through oxidative stress in rat model. doi: 10.1155/2012/194829

35. Lee Y-J and Shacter E (1999): Oxidative stress inhibits apoptosis in human lymphoma cells. J. Biol. Chem., 274:19792-19798. 